\title{
Methods Applied by Russia to Forecast the Influence on other Countries
}

\section{Original article}

Received: $2021-10-22$

Revised: 2021-11-04

Accepted: 2021-12-04

Published: 2022-02-02

\section{Peer reviewed}

Double blind

Keywords: Russian strategic forecasting, strategic matrix, influencing other countries, Russian foreign policy, safety forecasting in Russia

This work is licensed under the Creative Commons Attribution-NonCommercialNoDerivatives 4.0 License

\author{
Jakub Słowik $^{1}$ A-F
}

ORCID (iD) $\underline{0000-0001-8297-8659}$

\begin{abstract}
Military University of Technology in Warsaw, gen. Sylwestra Kaliskiego 2, 00-908 Warsaw

A - Research concept and design, B - Collection and/or assembly of data, C - Data analysis and interpretation, D - Writing the article, E - Critical revision of the article, F - Final approval of article
\end{abstract}

\begin{abstract}
Objectives: The purpose of this article is to identify the quantitative and qualitative methods applied by Russia in planning exerting influence on other countries, including members of the Visegrád Group.
\end{abstract}

Methods: The research method used in this study consists in a systematic review of Russian and global political literature, as well as military literature, publications in the field of international relations, international politics, econometrics and forecasting, economy and management, in the aspect of the differences between the methods of forecasting the influence on other countries with respect to the methods described in international subject literature.

Results: The conducted analysis of documents enabled the identification and drawing the characteristics of the strategic forecasting methods that Russia may apply to influence other countries. The study also identifies the institutions as well as researchers who deal with the issues related to forecasting influence on specific countries in Russia.

Conclusions: Both the identified methods and the research centres focus on ensuring the effectiveness of Russian foreign policy that requires an accurate assessment of the current situation as well as detailed forecasts of potential events (scenarios) in the future. The method that deserves particular attention is the

\footnotetext{
${ }^{1}$ Jakub Słowik, M.A. - is a doctoral student at the Doctoral Studies Programme of the Military University of Technology, major in Security. His academic interests include international security and security in sports.
} 
strategic matrix method, which has probably been modified, but its essential elements are still functioning.

\section{Introduction}

In the light of Russia's recent actions: the threatening conflict with Ukraine, the likely inspiration of the emigration conflict in Poland and the Baltic States, the recent demands for a new international order, and the proposals of a new Yalta system, reflect specific processes that occur in Russian foreign policy. The result of these processes is the concept of the New Russian Foreign Policy (Baranovsky, 2016).The document, where Russia announced its aspirations to conduct an active policy in matters of international security, was signed on November 302016 by the President of the Russian Federation Vladimir Putin (Комитет Государственной Думьл По Международным Делам, 2022). The previous Concept of the foreign policy of the Russian Federation was published in February 2013. Such quick revision was justified by the Russian authorities with the necessity to adjust the key indicators to the changing international situation. In the last five years, Russia has modified nearly all its essential strategic documents, such as the war, maritime, and information security doctrines, that refer directly to foreign policy and security. In comparison to the document of 2013, the role of the 'Russian world' (Russkij mir) (Kościński, 2015, pp. 71-87) ideology, whose aim is to shape the manner in which Russia conducts its external actions, has increased significantly. The new concept states openly that the entity that will support the actions of Russian authorities and diplomatic organs will be the Russian Orthodox Church. It is also planned to strengthen the role of Russian media as a source of information for foreign audiences, which is also proven by the content of the Information Security Doctrine of the Russian Federation, published in 2016. One of the tasks of the media is also to change the negative image of Russia throughout the world.

The analysis of documents related to Russia's recent activities reveals that the aim of Russian foreign policy is to gain the status of one of the leading centres of international politics. One should expect a further increase in Russian military potential and an increased involvement in the existing regional conflicts. It is also noticeable that Russian authorities will continue to attach great importance to foreign policy as a tool to shape the image of the country as an international empire in the perception of the Russian society.

It should be supposed that one of the reasons for such turn might be the growing internal problems that result from the weakening economy and failure to handle the COVID-19 pandemic, as well as problems in neighbouring countries that belong to the Russian zone of 
influence (Belarus, Kazakhstan). The aim of these actions is to distract the society from everyday economic problems as well as frequent cases of power abuse towards disobedient citizens.

However, it should also be noted that not only the authorities, but also a major part of Russian elites, as well as a large group of citizens have tended, historically, but also mentally, towards dominating other countries, on the local, regional, but also global scale. At the same time, what is characteristic for Russian influence on other countries is the fact that various actions are performed in a comprehensive, integrated manner in various areas, such as foreign policy, military and defence policy, economic policy, financial policy, energy and raw materials policy, climate policy, demographic and social policy, science and education, and, last but not least, these actions also include the area of terrorism. Regardless of the time and place, the resultant of individual activities of Russia has basically one aim: to protect the national interest of 'Great Russia', including maintaining, obtaining, or recovering the influence gained earlier. This claim is confirmed by the words of Winston $\mathrm{S}$. Churchill, who said, in the interview for BBC radio on October 1 1939: 'I cannot forecast to you the action of Russia. It is a riddle wrapped in a mystery inside an enigma. But perhaps there is a key. That key is Russian national interest' (Churchill, 1939; Clark, 2019).

The review of provisions on international relations in Russian strategic documents and analytical materials reveals that most of them do not differ significantly from similar provisions used in democratic countries. However, some of them still pursue the imperial arrogance that is well-known from the Soviet era. Sometimes, one may have the impression that Russian politics is characterised by dualism in form of a mixture of Occidentalism and Asian features. This is manifested in the penetration of either the idea of a new, globalised world, or the traditional Russian imperial mentality to the strategy and politics. Having noted positive changes in several fields, one has to state that in many situations Russia is still standing with 'one leg' in the traditional, difficult to define, which - Westphalian, bipolar or cold-war - understanding of sovereignty, occasionally demonstrating an imperial hypocrisy. An example is the refusal to allow neighbouring countries to make their sovereign decisions. Such attitude of Russia was experienced, for example, by countries that applied to join the North Atlantic Treaty Organisation, including Poland, in particular during the first round of NATO expansion. Currently, this also applies to the aspirations of Ukraine and Georgia. Another example is the development of conventional and strategic arms in 
policies towards the so-called 'near foreign countries' and increasingly frequent cyberattacks on countries that are considered not friendly to Russia. Another thoughtprovoking aspect is the fact that national authorities in Russia are taking over the energy policy, especially with respect to oil and gas, in spite of the apparent market economy. One should also consider that Russia carries out well-planned and organised attempts, using both political and market-related factors, to monopolise or, wherever possible, to take over the supplies of these raw materials to neighbouring countries, but also to Western Europe. The growing dependence of these countries, including Poland, may be used for political purposes or become a subject of blackmail.

However, it should be noted that the forecasts of Russian analysts state unanimously that, at the current stage of development and with the current distribution of economic and military forces, Russia cannot compete with other countries as an industrial power. If it entered such competition, it would have to focus on exporting raw materials, in particular power, to build capital and re-industrialise towards modern, competitive manufacturing forces. On the other hand, in the area of regional or global leadership, including the return to neo-imperialist concepts, it seems that the current government is trying to avoid the mistakes of former tsars and commissaries. The Empire and the Soviet Union were never profitable for Russian citizens. Russia has spent more money on maintaining and sustaining the dependent countries than the profits generated from them were worth. Ultimately, it was the subordinate countries that became one of the reasons of the fall of the Russian Empire. Modern Russian strategy seems to be different. Russia does not wish to take responsibility for the internal stability of these countries or their economic well-being. The essence of Russian influence is gaining negative control over the foreign policy of neighbouring countries, so as to prevent them from becoming a threat for Russia or a base from which foreign countries might conduct their actions against Russia. Precisely such policy may be applied towards the members of the Visegrád Group. These countries are Member States of the European Union and NATO members at the same time. Initiating and maintaining negative phenomena in their societies, which is connected with loosening the homogeneity of the EU, is combined with weakening the unity of NATO. The practical aspect of exercising 'negative control' is noticeable, for example, in Internet networks, including those related to the coronavirus or in publications (Trenin, 2020).

The end of the Yeltsin era was marked by another increase in the significance of the security 
apparatus, which signalled the end of the imbalanced transitional period in Russia. This growth also meant a potential threat for the new independent states on the peripheries of Russia, as well as for NATO (Saunders, 2019). From the Russian point of view, what happened in the peripheries were uprisings, openly supported by the West, which undermined the Russian negative control. The most important one too place in Ukraine, which embodies the main Russian national interest. According to Russian strategists, the basis of the European peninsula is the line from St. Petersburg to Rostov. This is also the line that separates Russia from the Baltic States, Belarus, and Ukraine. It has always represented the minimum security buffer that Russia had to have in order to resist potential attacks from the West. After the Baltic States were absorbed by the NATO, maintaining negative control over Belarus and Ukraine became vital for Russian national security. The transformation in Ukraine caused two processes. One of them was the resurrection of the Russian army as an effective regional force. The second were the formal destabilisation strategies applied by Russia. The culmination was the war with Georgia in August 2008. One of its aims was to demonstrate that the Russian army cannot be further rejected as a power, and to prove the voidness of American guarantees. The United States, who were then involved in wars in the Islamic world, were unable to help Georgia. These wars opened an opportunity for Russia to exert influence on the peripheral areas, including passing a message to the Ukrainian people: 'This is what American guarantees are worth'. On the other hand, during the events of 2014, when the government of Yanukovych was successfully overthrown, the Russians started to treat it as a coup performed by the Americans. This was also a major defeat of Russian intelligence services. Russia failed to foresee the events that resulted in forming a new government of Ukraine, it failed to block or challenge the processes, and their attempts to generate an uprising in the eastern part of the country was a major defeat. They were left with the Crimean, where they had always dominated, and with a narrow part of East Ukraine, which they have to fight for. Currently, Ukraine poses a double threat for Russia. Firstly, the buffer zone for Russia has been removed, which, with time, might become extremely dangerous. Secondly, the reputation of the FSB related to the maximum effectiveness of the formation, which used to be one of the foundations of the FSB's power and influence, has been undermined. It may also be noticed that the 'Ukrainian lesson' has been learnt and put into practice during the events in Kazakhstan in January 2022. It took Putin practically several hours to create 'the allied peace forces' which, in another several hours, suppressed the insurgency. 
The main economic problem of Russia is the lack of transformation of revenues from energy into a modern industrial and technological base. The Russian economy remains dependent on the export of energy, whose prices change. The periodical weakening of Russian economy, together with decreasing revenues from oil, has weakened the country. These negative phenomena have been reinforced by financial sanctions, which, in turn, amplified other economic problems. Thus, although Russia became involved in its exposed southwestern flank, it also has to deal with economic difficulties. The Ukrainian crisis, economic cycles, and American sanctions have produced a negative synergy.

As far, as future is concerned, the situation of Russia is extremely difficult. Its economic and strategic situation has worsened, and the development indicators are uncertain. Further deepening of these negative phenomena may be an intensive test of Russia's power and stability. Considering the economic reality and disadvantageous correlations of powers, the question arises, whether Moscow will be able to maintain both the Russian economy and territorial integrity? If not, then the Federation itself is threatened.

The existing internal and external conditions stimulate Russia to take actions that resemble the strategy of Quintus Fabius Maximus during the Second Punic War (Appianus of Alexandria, 2013). Fabius decided to avoid an open battle with Hannibal's army attempting rather to exhaust the Carthaginians. This strategy allowed him to prevent the siege of any of the cities. He notoriously hassled Hannibal, and then pushed his armies to the mountainous regions of the Apennine Peninsula, where the Carthaginians were unable to make full use of their cavalry. He also managed to disrupt Carthaginian supply chains. The strategy of Fabius consisted not only in avoiding battle to gain some time, but it was calculated to influence the morale of the enemy, and, even more, to influence their potential allies. Confronted with a disadvantageous balance of powers, Fabius may have avoided open battle, yet he remained sufficiently close to Hannibal to remain a constant threat.

The conditions in which Russia is currently operating are complex, unstable, and uncertain. However, Russian analysts are able to reasonably estimate the current position of Russia in the international power structure and to forecast this future position in a rational way. The Russians are impressed by ratings, so, depending on the position of the given country in a ranking, they may behave either as a merciless dictator, e.g. in Georgia in 2008, or they may adopt the strategy of an apparently withdrawn, weaker entity that is waiting for the right opportunity. This is the strategy that was applied by Quintus Fabius Maximum, who waited 
for the proper conditions in the future to start the deciding attack at the right moment. ${ }^{2}$ One may have the impression that the recent actions of Russia reflect those rankings, which may point to the possibility to make bolder demands towards the USA or the EU.

The referenced information is used to identify potential areas to conduct forecasting works connected with the realisation of the concept of Russian negative control. The prerequisite for the success of such strategy is access to information, as well as the ability to forecast the development of the situation in specific areas of interest. The methods of creating rankings that may be the basis for Russia to assess its current position among other states will also be presented.

\section{Research methodology}

The answer to the question what forecasting methods are used by Russia in planning and coordinating its influence on another country is complex, fragmented, and it cannot, by any means, be exhaustive:

- The complexity results from the fact that Russia uses various methods and does so in an integrated, comprehensive way. However, this complexity depends both on the field and on the country, as well as on the information sources used;

- The diversity and scattering result from the fact that specialists use integrated methods that employ the full range of possibilities and the wide achievements of Russian science in the field of probability theory (Khinchin, Kolmogorov, Tshebyshev, Lapunov, Markov, Ostogradsky), statistics (Tshupurov, Yesipov, Smirnov) systems theory (Sadovskiy, Bogdanov), economic models (Leontief, Hurwitz, Arrow, Slutsky, Kondratiev) (Lukashin, 2002, 2003, 2010, 2017);

- Many forecasts are realised upon orders by Western centres and agencies, many unpublished and confidential prognoses are accessible only to a narrow group of researchers, politicians, and authorities, as well as members of the Russian armed forces.

The main research method used in this study is a systematic review of Russian and global political literature, as well as military literature, publications in the field of international relations, international politics, econometrics and forecasting, economy and management, in

\footnotetext{
${ }^{2}$ Such battle finally took place on the $19^{\text {th }}$ of October 202 B.C., and ended in a devastating defeat of Hannibal.
} 
the aspect of the differences between the methods of forecasting the influence on other countries with respect to the methods described in international subject literature.

The author performed a systematic review of publications by international and Russian authors, concerning the methods of forecasting Russian influence on other countries, listed in the following databased: Web of Science, ScienceDirect, Ebesco, Scopus, Wiley, Springer, and Taylor \& Francis. The review covers publications and instances of publications that deal with the problems of modern Russia: published by government and non-government research centres, think-tanks, and academic associations, including: The Carnegie Moscow Center (The Carnegie Moscow Center, 2022), The Valdai International Discussion Club (The Valdai International Discussion Club, 2022), The Council on Foreign and Defence Policy (The Council on Foreign and Defence Policy, 2022), Stratfor (Stratfor, 2022), RAND (RAND, 2022), The International Institute for Strategic Studies (IISS) (The International Institute for Strategic Studies, 2022), The Stockholm International Peace Research Institute (SIPRI) (The Stockholm International Peace Research Institute, 2022), The Club of Rome (The Club of Rome, 2022), and The Economic Intelligence Unit (The Economic Intelligence Unit, 2022). The author also reviewed the articles that were published (in the last 10 years) in Russian specialist journals: Russia in Global Affairs and Nauka i voyennaya bezopasnost, publications of the Higher School of Economics in Mosco, Diplomatic Academy of the Ministry of Foreign Affairs of the Russian Federation, and The National Research Institute of World Economy and International Affairs.

\section{Characteristics of the sources used for forecasting by Russian researchers and forecasting experts}

The literature review and the analysis of sources used reveal that, apart from national sources (not all of which are known) Russian authors, researchers, and experts use the available sources of information provided by the international environment of experts and scientists. Apart from the institutions, organisations, research centres, and think tanks mentioned above, these include:

- international organisations (such as the United Nations, the World Bank, the ICF. OECD, and the EU);

- national and international statistical offices (Federalnaya sluzhba gosudarstvennoy statistiki, statistical offices of individual countries, and EUROSTAT);

- states and their agencies (e.g. the Government Centre for Strategic Studies in specific countries, intelligence and counterintelligence agencies); 
- universities and research institutes in specific countries;

- political parties and associations, trade union headquarters;

- private individuals.

In individual countries, the results of research, expert studies, and analyses published in various forms are monitored (some of the research conducted by intelligence and counterintelligence agencies is, obviously, confidential). They take the form of reports, studies, expert opinions, warnings, appeals, or articles published in academic journals. World-wide periodical (usually annual) reports are also monitored, including 'The Military Balance' (published by the International Institute for Strategic Studies - IISS), the 'SIPRI Yearbook' (published by the Stockholm International Peace Institute), and 'World Military Expenditures and Arms Transfers' (developed by the former U.S. Arms Control and Disarmament Agency - ACDA), 'Reports on the State of the World' (published by the Worldwatch Institute).

The publications by Russian scientists also take into account research programs that focus on gathering and processing information and simulating the course of global processes. The best known ones are The Correlates of War (The Correlate of War Project, 2022) and International Futures (International Futures, 2022). The Correlates of War is a research project that focuses on collecting, disseminating, and using accurate and reliable quantitative data in the field of international relations. It was established in 1963 by J. David Singer, a political scientist at the Michigan University. The original aim of the project, which is still pursued, is to systematically gather scientific knowledge about the war (the collected information cover the period from the year 1816). In the initial phase of research, the project contributed to accumulating knowledge on international relations. Since November 2002, it has been continued by the Pennsylvania State University, which archived all available materials from the Correlates of War project and is currently expanding the data collection.

On the other hand, the International Futures (IFs) is a wide-scale, long-term, integrated global modelling system developed based on the idea by Barry Hughes. This is a tool for thinking about the future of our world. This system consists of the following sub-systems: demographic, economic, energy, agricultural, socio-political, and environmental, for 183 countries that interact with each other in the global system. The main aim of the project is to facilitate research on global futures based on alternative scenarios. The model is linked to a vast database that covers the period from the year 1960. The Ifs program is available free of charge online.

The Ifs was a key element of the project that analysed the New Economy, sponsored by the 
European Commission. The forecasts obtained from the IFs program supported the Project 2020 of the National Intelligence Council (NIC) and Global Trends 2025 (Global Trends 2025: A Transformed World, 2008) developed by the NIC for the American administration that took the offices in 2009. The IFs program was also a source of targeted forecasts for the fourth Global Environment Outlook as a part of the United Nations Environment Program (United Nations Environment, 2019).

The authors of the analysed publications also mention the COPDAB (Conflict and Peace Data Bank Project) research project, which was created in the 1970s (Azar, 2009) as a response to the demand of scientists, journalists, historians, and employees of the public and private sectors for information that might help them decipher and explain the complexity of the world observed. The main aim was to monitor phenomena that cause wars, instability, and international tensions, but also those that lead to balanced interdependence, integration, peace, improving the quality of life, reducing colonialism, etc. As part of the project, procedures and theories were proposed that systematised the observations and contributed to improving the analytical competences. On July 1 1979, the computer database contained approximately half a million pieces of information that documented such phenomena as treaties, visits, tensions, boycotts, mobilisation, or wars. They originated from over 70 written sources from 135 countries (including Poland). Another research project that is quoted by Russian authors and experts is the Country Indicators for Foreign Policy (Country Indicators for Foreign Policy, 2022), which was initiated in 1991, developed and elaborated by the Canadian Department of Foreign Affairs and International Trade. Its aim is to gather statistical information that reflects the key features of the political, economic, social, and cultural environment of the world's countries. Nowadays, the database contains such information in form of more than 100 indicators for 196 countries form the period of 15 years (1985-2019). It is currently in the fourth phase, focusing on further consolidation and development. The access to the database is free of charge.

Authors of Russian publications also use information from associations that group people and institutions interested in forecasting (futurology). These include, among others: WorldFuture Society (World Future Society, 2022) and World Futures Studies Federation (World Futures Studies Federation, 2022). Numerous periodicals devoted solely or mainly to forecasting are used. Typical futurologist journals include, among others: the 'Futurist', 'Futures Research Quarterly', 'Futuribles', 'Future Survey' (issued in the years 2003-2008; since 2009 as the 
'World Future Review'), 'Futures: The Journal of Forecasting and Planning'; 'Journal of Forecasting', and the 'International Journal of Forecasting'.

Another source of important forecasts for Russian specialists and researchers is the American corporation Jane's, which aims to be 'he leading source of open intelligence information' and considers it its mission to 'support its customers in making the right decisions'. It operates in four thematic areas: defence, security, law/public security, and transport.

The American Central Intelligence Agency (CIA) may be another source of valuable information. It may be noticed that Russian authors widely use the resources of these institutions, while, at the same time, they do not disclose their own ones.

Another institution that has to be mentioned here is the American think tank RAND Corp. It is a non-profit organisation which was originally established for the U.S. military forces after the Second World War. It was created in 1948. The organisation employed some prominent scientists, including Nobel Prize winners. RAND developed, among others, the Delphic method and the methodology of making political and military and economic decisions that is known as the 'systems analysis'. Moreover, it helped implement the Planning, Programming and Budgeting System at the Ministry of Defence in 1961. Currently, RAND is conducting widescale studies on security and defence, terrorism, education, and public health.

Another organisation is the Stockholm International Peace Research Institute (SIPRI) that launched an official website called FIRST (Facts on International Relations and Security Trends) (Facts on International Relations and Security Trends, 2022), which is addressed to scientists, politicians, journalists, and the media. It offers a reliable and structured system of actual information (reference) on the trends in international relations and international security. The service includes up-to-date, high quality, clearly documented information from the following areas:

- conflicts, transfers of arms and military expenses;

- hard data about states and international organisations;

- economic and social statistics;

- chronologies (periods and events presented chronologically).

Another project by SIPRI, which is a specific forecasting model, is the Early Warning Indicators for Preventive Policy, which was launched in 2002. It offers a synthesis of monthly experts' comments, selected statistical data, and the possibilities of the Internet and creates a new basis 
in the field of early warning indicators. According to the organisers, processing data from polls and statistical data will enable to create indicators that will point to the negative trends in the national, regional, social, political, and economic aspects.

Russian publications also list an important source of diagnostic and prognostic information, being the Economist Intelligence Unit, which is a branch office of The Economist Group (the publisher of 'The Economist' weekly magazine) that, according to its own statements, is responsible for conducting business research. It uses the support of a global network of experts (consisting of over 650 cooperating specialists) to provide ongoing evaluations and forecasts of the political and economic conditions in 200 countries. As a global leader in gathering information about individual countries, it helps managers make better decisions by providing them with up-to-date, accurate and objective analyses of global market trends and business strategies.

\section{Theoretical basis for forecasting in the publications of Russian authors}

Forecasting consists in predicting the future in a scientific way. It is characteristic for any human activity. Forecasting the influence of Russia on other countries means predicting the international relations (international policy). It means forecasting strength on the one hand, and predicting the weaknesses on the other hand. This is done in multiple areas: energy (Baykov et al., 2012), climate (Korzun, 2012), raw material resources, demography, security systems, defence systems, science, culture, economic, social and political relations (Semenenko et al., 2014). The elements that are becoming increasingly noticeable include the interest in psychological influence, e.g. actions aimed at weakening the social capital in selected countries, including forecasting the ways and effects of using social media.

The Russian way of forecasting is a set of complex research activities, methodical, procedural, and organisational actions with the aim to obtain science-based information about the future development of processes and phenomena. The final result of the forecasting process is the forecast (or forecasts), preparation of plans, programs, and then activities (Lukashin, 2002, 2003, 2010, 2017; Pantin, 2003). These forecasts usually specify the nature of future international relations, in particular relations of power, political and military tensions, conditions for peace, integration and disintegration, the state of resources and the environment, resource availability, etc. All these actions are conducted on a very wide scale, covering large areas, and also with use of so-called soft forecasting (Dynkin et al., 2018). 
According to Russian authors, forecasting (similarly to all decision-making processes) consists in processing information, or, more accurately, in obtaining, gathering, segregating, classifying, generating, processing, filtering, and transmitting information. This process, especially in its more advanced stages, takes place within a defined organisational (institutional), methodological and technical framework (Pantin et al., 2016).

In general terms, a forecast is a prediction based on the knowledge of past events. It is usually expressed in terms of probability. Hence, a forecast is a statement about the probability of occurrence of a specific event in the future (Arbatova et al., 2016; Dynkin, 2013).

Complete prognoses should be characterised by three properties: they should state 'what' will probably happen, 'when' it will happen and 'how' (Doran, 1999). However, not all forecasts are like this. Some of them omit the explanation 'how' the given phenomenon or process will lead to a specific result. These forecasts do not have an explanatory base, i.e. they do not require demonstrating the correctness of interpretation. Charles Doran refers to such forecasts that answer the 'what' and 'when' questions, yet are not accompanied by an explanation as 'alpha' type forecasts (Doran, 1999).

The second type of forecasts are those that specify 'when' something will take place, but do not provide a specification of the sequence in time. These are referred to as 'point' forecasts. For most politicians, these are the only forecasts that receive the minimum acceptability. The old saying by George Washington 'To be right at the wrong time is to be wrong' contains a wisdom and a warning for all forecasters that anything less than a raw point forecast has no significant political value (Doran, 1999).

However, most forecasts are 'beta' type forecasts, i.e. statements about the future that omit both the explanatory base and time specification. They do not state 'when' an event will take place nor 'how'. 'Beta' type forecasts only state that something will happen. Still, even those forecasts are difficult to make credible.

Forecasting is a set of research procedures, methods, and techniques that focus on improving the understanding of the future. The aim of forecasting studies is not merely to predict specific future events, but also to provide support in improved decision-making by offering a wide range of various types of available information. At the same time, it is more important whether the forecasting analyses help decision-makers than whether the forecasts themselves are good or bad. In very general terms, forecasting as a method of predicting the future may be (Semenenko et al., 2014): 
- rational;

- irrational.

Forecasting may be considered as rational, if the process of creating the forecast is based on logical thinking, starting from the analysis of a set of facts from the past i.e. from the rationale (the phase of diagnosis) and proceeding to conclusions (the phase of forecasting the future). Rational forecasting may be scientific (based on the principles of science) or common sense (based on life experience). Irrational forecasting occurs when the prerequisites are not provided and (or) the link between the rationale and the conclusion has not been maintained (Dynkin et al., 2018).

Practical approaches to forecasting may be divided into groups based on various criteria. According to one of the proposed options, four main approaches may be distinguished (Semenenko et al., 2014):

- data-oriented (empirical, experimental and empirical);

- model-oriented (analytical);

- approach that combines two previous methods, i.e. data and models (iterative);

- goal-oriented (teleological);

- contradiction-oriented (dialectic).

The empirical (or experimental and empirical) approach is based on the empirical evaluation of existing data, including opinion surveys, with use of quantitative analyses developed in statistics and econometrics. On the other hand, the basis for the analytical approach is a welldefined theoretical model that attempts to explain the mutual relationships between a small or large number of variables. Such model has the form of an equation (or a set of equations). The left side of the equation contains the variables explained by the model (so-called endogenous variables) and the right side contains the explanatory variables. It is important to capture the most important variables while creating the model, so the issue of data availability should not be a limiting factor for the person who creates it. Typical forecasting techniques used in this approach include correlation and substitution analysis.

The analytical and empirical approach takes into account the availability of empirical or experimental data that support the hypotheses of the theoretical model. Sometimes, the process is reversed - the theoretical model that best explains the observed data and phenomena is created based on the available empirical models (data, experiment results, or historical experience) (Lukashin, 2002, 2003, 2010, 2017). 
The analyses conducted in the teleological (goal-oriented) approach acknowledge explicite the interactions between the created forecasts and the event that will actually take place. In this approach, the world without the forecast would be different from the one where the forecast has been developed. Finally, the dialectic approach is based on the assumption that both the past (history) and the future are sequences of conflicts and that the actual content of the system (or of past and future events) is the result of a highly complex process that depends on the plan or working hypothesis (Lukashin, 2002, 2003, 2010, 2017).

In Russia, methods of analysing international relations, including forecasting methods, are divided into qualitative and quantitative ones (Pantin, 2003). Qualitative methods involve a multi-variant description of events and phenomena with the contribution of experts' knowledge, experience, and intuition. They are considered to be 'richer' than quantitative methods. The latter operate on variables that take the numerical form. Some scientists believe that they may be applied only to relatively simple descriptions. However, this classification, although it is justified due to educational reasons, is a very simplified, artificial approach.

\section{The extrapolation method}

This is probably the most commonly used method of forecasting, which consists in projecting the noticed tendencies or trends onto the future. In other words, this means drawing conclusions about development tendencies, relations or values outside a given range based on what has been observed so far. In forecasts, it is usually applied in form of extrapolating the trend function, regression models, correlation models, or econometric dependencies (Lukashin, 2002, 2003, 2010, 2017).

Most forecasts are created with use of the extrapolation method that consists in extending the noticed tendencies or trends into the future. Although this is rather simple, the forecaster has to define, how far into the future the forecast should reach. If the future events will really resemble previous ones, the forecast may be quite accurate. Unfortunately, such cases are rare, the more so, the farther the forecasts reach into the future. Usually, a non-linearity or discontinuity occurs. Nonlinearity is a critical point of all forecasts that is caused by a deep and sudden change of trend, in fact a radical reversal (Brings, 1978). This is why extrapolation cannot be used for long-term forecasts. 


\section{The analogy method}

This method is based on similarities and correlations between events that occurred in the past and that may take place in the future in a similar form. Apart from historical analogies, which usually bring good results in forecasting international relations, biological, temporal and spatial, mechanical, hydraulic, and pneumatic analogies may also be applied. However, forecasters who use this method should beware of false analogies that often present as apparently obvious (e.g. comparing the market to a battlefield, an example may be the historical analogy concerning Roman strategy during the Second Punic War, discussed above). Metaphors are a weaker form of analogies.

\section{Heuristic methods}

Heuristic methods are a set of methods used to solve any problems, including forecasting ones, in a creative way. They are connected to the so-called intuitive approach and include various methods and techniques, such as expert methods (the most popular ones are 'brainstorming' and the 'Delphic method'). Heuristic methods have been contrasted with algorithm-based methods (i.e. those based on the application of a specific algorithm or procedure that leads to solving a problem in a finite number of steps), but nowadays this opposition has become less important. Currently it is believed that both heuristic and algorithm-based methods have a common core and that a sensible combination of both methods should be sought to solve various tasks.

\section{The morphological analysis (method)}

In fact, morphological analysis belongs to the category of heuristic methods, although there are several good reasons to discuss it separately. Although it originates from engineering, it may be applied more widely. It is a method that analyses the properties of the form (external structure) and properties of structure (internal structure) and the links between them. In a wider perspective, this refers to searching for all possible parameters of a dataset and their relations in order to find new, valuable combinations (in form of products or processes). Morphological analysis is not a forecasting method in itself, but it is a very useful tool, as it enables generating an enormous number of scenarios.

\section{Scenario method}

The term 'scenario' has multiple meanings. From the point of view of international forecasting, it may be assumed that it is an outline of a series of hypothetical (supposed, 
assumed) events with the aim to determine how the object (system) will develop. Scenarios are an indispensable element of experiments, exercises, manoeuvres, and computer simulations, as well as decision-making games (managerial or strategic ones).

\section{Modelling and simulations}

Simulation is a research technique that enables imitating the actual processes, behaviours, decisions, and their results. To achieve it, abstract models (logical, mathematical, econometric, and statistical) are used, as well as graphic and physical models. Model-based simulations allow for non-invasive, relatively cheap experiments. In the narrow understanding of the term, simulations are computer simulations. The wider meaning also refers to widely understood experiments, such as decision-making games.

\section{Indicator method}

This method consists in applying certain structural indicators that are known (that may be implied or assumed) to be reliable, as they are logically or historically justified. Various indicators may be used in forecasting, e.g. GDP per capita, or the demand for food or energy.

Summary

In general, according to Russian studies and materials, the subject of forecasting the influence on other countries may be various processes and phenomena that occur in the system of international relations, in particular those that have been considered as essential. The subject of forecasting understood in this way may be, in particular:

- the potential and desirable directions of the development of science and technology and their influence on international economic, political, military, and cultural relations in the subjective, objective, and spatial dimensions;

- political and military processes that include the shaping of relations between countries, groups, or alliances, as well as inside those groups and alliances; the development of armed forces: their tasks, size, structure, nature, combat power, operational capacity (including deployment capacity); the intensity and nature of threats to the interests of states and societies (terrorism, the development of aggressive technologies, access to weapons of mass destruction);

- social and economic processes that include the formation of the dynamics and future trends of economic development (both in individual countries and inside integration groups or alliances) and of potential economic systems, and their influence on the 
nature of international relations that determines the scope and intensity of cooperation, competition, and fight;

- demographic processes, with particular focus on the length and quality of life, demographic structure, ageing of the society, the demographic rise and fall of states.

Russian forecasting methods used in international relations and diplomacy, including planning the influence on other countries, consist in a wide application of mathematical, statistical, and econometric models, as well as game theory models that are known and discussed in international literature and taught at international universities. Russian researchers, analysts, and experts have access to a wide range of global resources and are subsidised by the government.

\section{Russian models of forecasting influence on other countries}

As it has already been mentioned, Russian experts often use rating methods to prepare forecasts in various areas, including: wide use in economic ratings (Expert, 2022), or in rankings of educational facilities (Kincharova, 2014, pp. 70-80). The models that refer to the concept of rating analyses in forecasting international relations and that represent the Russian approach to forecasting are the Khachaturov model and the Strategic Matrix Model. It seems that these models are still functioning on the desks of Russian decision-makers, that they are appreciated, and that the generated ratings appeal to their imagination.

\subsection{The Khachaturov model}

An example of Russian forecasting of potential influence on other countries is the model developed by Vladimir Khachaturov (Khachaturov, 1997). In developing this model, Khachaturov relied on the history of civilisation, using works by well-known historians: Nikolai Danilevskiy 'Europe and Asia' (Danilevskiy, 1895), Oswald Spengler 'The Decline of the West' (Spengler, 1918), Arnold Toynbee 'A Study of History' (Toynbee, 1949), and Karl Jaspers 'The Origin and Goal of History' (Jaspers, 2014).Based on the analysis of vast historical material, he presented global patterns of development of specific regions and human civilisation, by distinguishing the following types of civilisations:

1. European (Europe, America),

2. Orthodox (Russia), which, as he noted, has evolved in the territories between Europe and Asia in the course of long-term historical transformations (including 
the era of the Huns and the Golden Horde), creating a civilisation that integrated the features of European and Asian nations and at the same time inherited the spiritual influences of Byzantium. Khachaturov also noted that, as history had demonstrated, the global geopolitical mission of the civilisation that emerged in the territories of the former Soviet Union (old Russia) is to act as a buffer and to unify the other civilisations (the West and the East, the North and the South).

3. Islamic (Arab countries, Iran, Turkey, Afghanistan, Pakistan),

4. Indian (India),

5. Chinese (China).

Based on the above classification, Khachaturov created a mathematical an geopolitical model of a world that is united yet still multi-polar. In this world, various countries that possess various resources, demographic potentials and military potentials create various alliances. As a result of various flows of resources (demographic, raw materials, energy, military, and others), different geopolitical poles emerge. Their number and potential influence the polarisation of the Globe, ensuring its stability. The Russian tradition of economic and sociological thought applies the inter-branch flow model by Leontiev (Ćwik et al., 2006, pp. 81-99) for describing and forecasting such phenomena. According to Khachaturov, the presence of such poles is the condition for global geopolitical stability.

Khachaturov uses the terms 'country potential' and 'potential of a group of countries', which are closely linked to the notions of the 'country authority (power)'. He also claims that there are quite many indicators of development of a given country that may be considered useful for assessing its potential: population, territory, total fuel and electric power consumption, Gross Domestic Product, national income, and others.

According to Khachaturov, in the united world, humanity may choose from only three paths of development: in a polarless world, a unipolar world or a bipolar world. Being a physicist, Khachaturov uses analogies from physics, which constitute the basis for his model ${ }^{3}$.

\section{The case of the 'polarles' world}

This case corresponds to two variants of development. In the first version, the world is represented as a single state: all states are united in a single block that is governed by global

\footnotetext{
${ }^{3}$ Vladimir Khachaturov is a mathematician and physicist, Head of the Department at the Computational Centre of the Russian Academy of Sciences.
} 
laws. Such world is not polarised, but it remains geopolitically stable. It may take the form of an authoritarian, totalitarian regime, because, if such state is to be preserved, power structures are usually created to maintain the status quo. According to Khachaturov, an example may be certain dictators who reached for power with democratic slogans and then introduced authoritarian governments. He provides the example of the democratic coup of Napoleon Bonaparte.

The second option corresponds to a completely disconnected world. It might emerge, for example, after a global disaster, when most states are destroyed. The world will lose connection and a set of disconnected states will emerge. It is possible to imagine a situation where separate groups of people (tribes, communities) live in some regions of the planet, while other areas are home to a set of disconnected states (groups of people). Such variant of geopolitically stable development of humanity existed at the early stages of our development. Such world will have to go through all the wars, geographical discoveries, and revolutions once again to restore the lost connections.

\section{The case of the unipolar world}

This world consists of only one block of states that groups only some of them and whose potential exceeds the total potential of all other states that are not parts of the block. Such world is not geopolitically stable. The pole is characterised by a relatively high material level of life of the population of the block of states and a relatively low level in states that are not members of the block. Apart from that, there is nothing to prevent this gap from widening with time. A geopolitical pole thus emerges. Such world is very dangerous for those states that do not belong to the pole: they may be treated as sources of raw materials or as a place to locate the most dangerous branches of industry or to dispose waste. Human life in those states may be reduced to a level of relative slavery (modern slavery).

Such geopolitical pole may form an oppressive regime, which is characteristic for authoritarian or totalitarian rule. With time, such geopolitical pole also becomes dangerous for its inhabitants: in the event of conflict with the government, they may be forced to move out to states outside the pole. The right to live in states of the pole will be treated as the greatest good so that it will be granted only to those who bring the most benefits to the regime and are obedient. This right may also be applicable to 'particularly outstanding' inhabitants of the external states. 


\section{The case of the bipolar world}

The world may remain geopolitically stable only in the unpolarised or bipolar variants of development, and all unipolar systems are geopolitically unstable.

Apart from geopolitical poles, Khachaturov also distinguished blocks of states, which he refers to as political poles. The sovereignty of the member states of such blocks depends on the agreements contained in the diplomatic treaties of a specific group of countries. Obviously, more than two such poles may exist. The idea of a multipolar world may apply to countries with a high or low potential. For the first ones, it creates an illusion of safety as it prevents uniting into blocks of a powerful potential, while for the latter, it retains the possibility to exert economic or military pressure on weaker countries, 'forgetting' about any diplomatic agreements whenever necessary, The concept of a multipolar world is thus similar to the 'divide and rule' idea that has been realised for centuries by powerful countries in various regions of the world.

Khachaturov concludes that the objective result of historical processes will be the emergence of geopolitical poles, and that political poles reflect the temporary agreements between entities that are involved in the actual historical process. Hence, the Khachaturov model will be useful for analyses conducted on such level.

For the purposes of such analyses, Khachaturov proposed a group of four indicators that reflect the potential and development level of the given country. These include: the surface area of the occupied territory, the population, total annual consumption of primary energy resources (coal, natural gas, and oil) and the volume of energy consumed annually by households. The 'country's potential' defined in this way (and closely linked to such terms as the 'power' of a state) is required to identify the geopolitical pole, i.e. the country (or group of countries) whose potential is not lower than the potential of any other group of countries.

According to Vladimir Khachaturov, the following indicators of potential may be determined for a given state:

- the surface area of the territory;

- population;

- total annual consumption of primary energy resources (coal, natural gas, and oil);

- the volume of energy consumed annually by households. 
The 'country's potential' defined in this way (and closely linked to such terms as the 'power' of a state) is required to identify the geopolitical pole, i.e. the country (or group of countries) whose potential is not lower than the potential of any other group of countries. Based on these indicators, Khachaturov presented 15 indicators of potential:

$$
\begin{aligned}
& -\mathrm{A}, \mathrm{B}, \mathrm{C}, \mathrm{D}(4) ; \\
& -\mathrm{AB}, \mathrm{AC}, \mathrm{AD}, \mathrm{BD}, \mathrm{CD}, \mathrm{BC}(6) ; \\
& -\mathrm{ABC}, \mathrm{ABD}, \mathrm{ACD}, \mathrm{BCD}(4) ; \\
& -\mathrm{ABCD}(1) .
\end{aligned}
$$

Khachaturov used the above indicators as a basis for distinguishing 15 sets of indicators used to compare two blocks divided according to the type of culture: the so-called Eastern and Western blocks. The Western block includes: Europe (without Turkey, Serbia, and some former Soviet Republics), USA, Canada, Australia, New Zealand, Latin America, and Africa. The Eastern block includes: the Middle East, Turkey, Serbia, Japan, China, India, other Asian countries, Africa (Islamic countries) and the rest of the former Soviet Union. The sets included single indicators (4), pairs of indicators (6), groups of three indicators (4), and one set consisting of all four types of indicators - altogether 15 comparisons. It turned out that in 12 cases the potential of the Western block was higher than that of the Eastern one.

In this way, Khachaturov's model demonstrated that in 12 cases out of $15(80 \%)$, the world is heading towards a unipolar, unstable variant with a geopolitical pole consisting of countries from the Western culture.

This discussion reflects the mentality and way of thinking of Russian elites, including academic ones. They are directed against the Western world, being the USA and Western Europe. In order for the world to remain stable, a bipolar system has to be maintained; with the Orthodox world with the spiritual heritage of Byzantium will be a counterbalance for the West. This is confirmed by Khachaturov's statement in the quoted article: 'There is one thing I know and I can tell you a secret, that, if Russia is saved, it may be only as a EuroAsian power and only because of its Euro-Asian nature. [...]. Our task is to thoroughly analyse the reasons of the fall of previous Euro-Asian blocks and to develop such foundations for the newly established Euro-Asian Union that will make it permanent. The new alliance must be attractive for all countries that wish to join it. Mechanisms should be developed that will transform the current centrifugal trends into centripetal ones. Such 
alliance will support not only the creation of a new state formation, but will also contribute to the sustainable development of all humanity towards a single civilisation on Earth' (Khachaturov, 1997).

This concept became reality on March 15 1996, when the Russian State Duma adopted the Decision on deepening the integration of nations that united in the Soviet Union, repealing the Decree of the Supreme Council of the RSFSR of December 121991 on the termination of the Treaty on the formation of the USSR. The Duma recommended that the President of the Russian Federation should develop a system of means to support further integration of the Russian Federation, Belarus, and other former Soviet republics, including conducting a country-wide referendum on the gradual strengthening of the unity of nations forming the USSR.

Such model shapes the approach to the forecasts and international analyses conducted by Russia. The concept of the Euro-Asian Empire with its zones of influence assumes the creation of a system, where a certain group of states will play the role of a buffer zone to protect the Euro-Asian Orthodox pole. The presence of such model may also be noticed in the New Foreign Policy of Russia, mentioned before.

\subsection{The strategic matrix method}

The Strategic Matrix Method belongs to the group of rating methods. It consists in a graphic representation of the potential of a country, which is based on nine fixed indicators with scales of comparison. The method is universal, i.e. it allows to present the level of 'power' of various countries, taking into account different historical periods. The aim of the matrix is to forecast both present and future potential of individual states based on the so-called 'integrated indicator of power'. It integrates the application of elements of the logical theory, graph theory, and the scenario method. Such methodology provides tools for analysing the history of individual states, blocks of states, and regions, as well as for preparing forecasts of their development.

The strategic matrix method is a development of multi-factor analysis and social dynamics. This method is used to analyse the power of specific countries and regions (Kuzyk et al., 2004). The authors who made key contributions to the development of this method are: N. Kondratiev, P. Sorokin, and I. Prigogine. The review of related subject literature reveals that studies on forecasting the 'power' of states with use of the strategic matrix method are 
conducted by the following Russian centres: the International League of Strategic Management (MSLU) (International League of Strategic Management, 2022), the Institute of Economic Strategies (INES) (Institute of Economic Strategies, 2022) and the International Academy for Future Studies - Forecasting Academy (MAIB) (International Academy for Future Studies - Forecasting Academy, 2022), the Academy of Economic Strategies (NPP) (Academy of Economic Strategies, 2022), and the Institute of Economic Strategies (Institute of Economic Strategies, 2022). Publications by authors from these institutions allowed to identify the main relationships of this method, and then to determine the indicators of 'power' of Russia, the USA, and members of the Visegrád group (Ageev et al., 2008; Kuzyk et al., 2004).

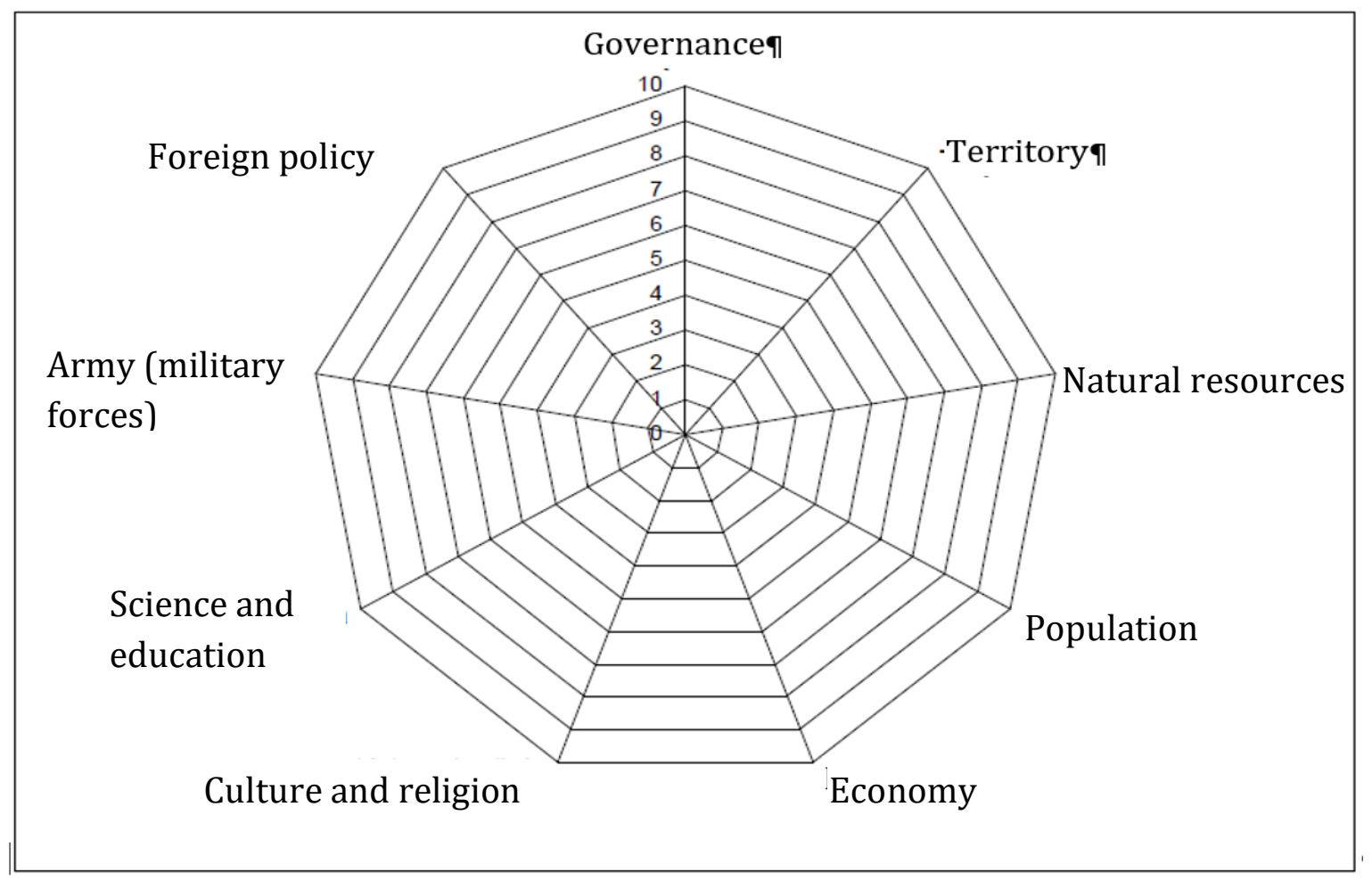

Fig. 1. Enneagram of the strategic matrix

Source: (Kuzyk et al., 2004, p. 18).

The strategic matrix is presented in form of an enneagram (Fig. 1.). The graphic presentation of a multi-factor model enables to identify the strategic development directions of a state in the given period.

The analysis of the relationships and interactions between all possible factors listed by the scientists constituted the basis for selecting nine most important ones for the dynamics of the development of the state. These include: governance (management) method, territory, 
natural resources, population, economy, culture, and religion, science and education, army (military forces), and foreign policy (the geopolitical environment). These factors are defines based on available statistical data and they are evaluated with use of specially designed weight criteria and assessments of experts.

The enneagram of the strategic matrix is a graphic representation of various factors that secure the development potential (territory, natural resources, population, culture, and religion) and its realisation (economy, science, army, and foreign policy). The 'governance' parameter is analysed as a factor that is a synthesis of all other elements, and thus it is considered separately.

As a result of combining these nine parameters, a nonagon is created, which, after taking into account the obtained score (from 1 to 10) is a graphic representation of the power of a state that illustrates the condition of the state system. An increase or decrease in the profile volume indicates a specific trend of the evolution (state development) vector: the system is either growing stronger and expanding or tending towards degradation or even decomposition. Thus, the application of a multi-factor model allows diagnosing the stability of a state. Excessive development of certain factors with a simultaneous insufficient development of others generates risk of system destabilisation. The perfect model of a wellbalanced state is a polygon inscribed in a circle, with evenly power indicators that are as developed as possible.

The authors of the strategic matrix propose a four-degree scale to evaluate the indicators. The score may range from 1 to 10, depending on the significance. The proposed ranges of scores provide a possibility to position states within specific groups (Table 1). They are the same for all nine parameters:

Table 1. Assigning value to indicators within a group of states of similar status.

\begin{tabular}{|c|c|c|c|}
\hline Status of the country & Below average & Average & Above average \\
\hline Superpower & 8 & 9 & 10 \\
\hline Large power & 5 & 6 & 7 \\
\hline Regional power & 2 & 3 & 4 \\
\hline Small state & 1 & & \\
\hline
\end{tabular}

Source: (Kuzyk et al., 2004, p. 20).

Apart from the nine basic indicators, the methodology also uses the so-called integral power 
indicator (IPI), which enables the generalisation of the values obtained for nine power indicators. The geopolitical 'weight' of the given state is defined as the average score of the nine variables, which depends both on internal conditions (the country's status) and the external conditions (its environment).

The dynamics of changes in geopolitical status is determined with use of a total state power indicator in two meanings: as the total state power indicator before a historical event (R1) and the total state power indicator after a historical event (R2).

In order to correctly evaluate the geopolitical environment of a state, the following indicators are used:

$\mathrm{S}_{\mathrm{i}}$ - status of country $i$

$\mathrm{K}_{\mathrm{i}}$ - the degree of conflict in the relations between state $i$ and the analysed state.

The degree of conflict $\left(\mathrm{K}_{\mathrm{i}}\right)$ is also assigned a score depending on the nature of the relationships, i.e.: allies (4), partners (2), neutral (0), rivals (-2), enemies (-4). The values of the country's status and the degree of conflict in its relations with the environment allow us to evaluate the geopolitical environment of a state by means of the 'allies - enemies' relation.

$\sum_{(1) i=1, n} S_{i} \cdot K_{i}$ - significance of the 'allies/enemies' relationship before a historical event $\sum_{(2) i=1, n} S_{i} \cdot K_{i}$ - significance of the 'allies/enemies' relationship after a historical event Due to the fact that the 'allies/enemies' relationship has a significant influence on the geopolitical status of the state, but it is also derived from this status, the above formula was developed to calculate the global geopolitical potential of a state (here: Russia $-\mathrm{R}_{\mathrm{u}}$ ):

$$
R_{u}=R_{2}+\frac{R_{2} *\left(\sum_{(2) i=1, n} S_{i} * K_{i}-\sum_{(1) i=1, n} S_{i} * K_{i}\right)}{R_{1} * 100}
$$

In formulating the significance of the global geopolitical potential, the total power indicator is treated as a priority due to its stability. Comparing the power of states with use of the total indicator provides an answer to the question about the positions of individual states in the international system of power. 


\section{Conclusions}

According to its authors, the strategic matrix is one of the main tools of the strategic management and planning theory. The main terms that describe the process of strategic management are the state of the system and the process of transition from one state to another. The state of the system is the effect of a historical process defined as the innate and acquired properties that have changed in the development process and under the pressure of the external environment, own specific purpose, and own needs of the evolution. The evolution of the system takes place under the influence of internal and external factors.

Both the indicators include in the strategic matrix and the matrix itself provide a basis for determining the position of a state. The multi-factor model allows for identifying the condition of the state and the values of specific state power indicators. The development of certain factors with a simultaneous insufficient development of others generates risk of system destabilisation. The best of all currently known state development models is the model whose graphic representation is a nonagon inscribed in a circle, with equal sides and with the power indicators developed as strongly as possible.

The graphic representation of the elements of state potential offers the possibility to read and interpret each of the factors individually and a synthetic overview of all the factors. The strategic matrix illustrates the historical cycle of transformations of a given system, which is a presentation of factors and events in which it participated and still participates. This method allows not only to present the data during the lifetime of a system, but also to present the country as a dynamic system. Moreover, the application of the strategic matrix neutralizes the effects of incomparability of such factors as: culture and religion or science and education. Besides, the matrix highlights the dependence between the dynamics of state development and politics and global economy (general openness, the degree of dependence on the external world, development directions and global economic cycles).

The strategic matrix method may also be used for forecasting purposes. In forecasting the changes in the position of a state, the matrix methodology is based on the scenario method, which enables to describe various hypothetical variants of changes as a system of mutually interconnected phenomena. Hence, in forecasting the development of the international situation, four scenarios are analysed: 'Hard globalisation', 'Moderate globalisation', 'Regionalisation' (where two scenarios, 'positive' and 'negative' are considered), and the 
'Chaos' scenario. The scenarios mentioned above have become the basis for forecasting the development prospects in international relations between states and other subjects of international relations, as well as for evaluating the dynamics of the changes in the international position of states.

Thus, the strategic matrix may be used by decision-makers who are responsible for making strategic decisions as a form of data structuring. It also provides information about the state of the managed systems and the directions of their changes, as well as practical approaches to the development and implementation of strategies. The current degree of elaboration of the multi-factor analysis methodology (the strategic matrix) allows us to refer to it as a universal method, because it may be applied to analyse the degree of development of states in various historical periods, and, apart from that, it may be the basis for forecasting.

Such analyses and presentations that may be prepared with use of the strategic matrix model, which enable to evaluate the power of a country or a block of states, may allow Russian strategists to direct their actions aimed at reinforcing Russian national interest, including negative control activities in the buffer states that protect the Empire, as well as to monitor the current situation and position of powers, providing information whether a convenient moment may approach for more decided manoeuvres that might strengthen the position of Russia.

\section{References}

Academy of Economic Strategies (2022). Available at: http://www.russtrategy.ru/training/aes/. Ageev, A. et al. (2012) Globalnyy reyting integralnoy moshchi 100 stran. Moskva: Mezhdunarodna Akademia Issledovaniy Budushchego.

Ageev, A. I. et al. (2008) Osobennosti primenebiva metodologii strategicheskoy matritsy pri prognozirovanii razvitiva gosudaratv (na primere Rossii i Kitaya). Moskva: Institut ekonomicheskikh strategiv.

Appianus of Alexandria et al. (2013) Appian's Roman history. Cambridge: Harvard University Press.

Arbatova, N. K. et al. (2016) A Global Strategy for the European Union Foregin and Security Policy. Moscow: IMEMO.

Azar, E. E. (2009) 'Conflict and Peace Data Bank (COPDAB), 1948-1978', Inter-university Consortium for Political and Social Research (distributor). doi: 10.3886/ICPSR07767.v4.

Baranovsky, V. (2016)' Russia's New Foreign Policy: Implication for International System', Mirovaya ekonomika i mezhdunarodnye otnosheniya, 60(7), pp. 5-15. doi: 10.20542/0131-2227-2016-60-7-5-15. 
Baykov, N. et al. (2012) Forecast of development of fuel and energy in the world to 2035. Moscow: IMEMO RAN.

Brings, A. (1978) 'The historian and the future', Futures, 10(6), pp. 445-451. doi: 10.1016/0016-3287(78)90044-7.

Churchill, W. S. (1939) Churchill's Remarks on the First Month of the War. Available at: http://churchill-society-london.org.uk/RusnEnig.html.

Clark, J. R. (2019) 'Russia's Indirect Grand Strategy', Orbis, 63(2), pp. 225-239. doi: 10.1016/j.orbis.2019.02.002.

Country Indicators for Foreign Policy (2022). Available at: https://carleton.ca/cifp/.

Ćwik, B. et al. (2006) Podstawy ekonomii matematycznej. Warszawa: Wyższa Szkoła Ekonomiczna Almamer.

Danilevskiy, N. (1895) Rossiya $i$ Yevropa. Available at: https://imwerden.de/pdf/danilevsky_russia_i_evropa_1895.pdf.

Doran, C. F. (1999) 'Why Forecasts Fail: The limits and potential of forecasting in international relations and economics', International Studies Review, 1(2), pp. 11-12.

Dynkin, A. A. (2013) Strategic Global Forecast to 2030. Moscow: Magistr.

Dynkin, A. A. et al. (2018) Russia and the World: 2019 Annual Forecast: Economy and Foregin Policy. Moscow: IMEMO.

Expert (2022). Available at: https://raexpert.ru/ratings/methods/current.

Facts on International Relations and Security Trends (2022). Available at: http://first.sipri.org/.

Global Trends 2025: A Transformed World (2008). Available at: https://www.files.ethz.ch/isn/94769/2008_11_Global_Trends_2025.pdf.

Institute of Economic Strategies (2022). Available at: http://www.inesnet.ru/.

International Academy for Future Studies - Forecasting Academy (2022). Available at: http://www.maib.ru/.

International Futures (2022). Available at: https://pardee.du.edu/access-ifs/.

International League of Strategic Management (2022). Available at: http://www.russtrategy.ru/about/.

Jaspers, K. (2014) The Origin and Goal of History. Berlin: Routledge.

Khachaturov, V. (1997) Rossiya $i$ geopoliticheskaya stabilnost mira. Available at: http://gumilevica.tripod.com/Matter/Article09.htm.

Kincharova, A.V. (2014) 'Metodologiya mirovykh reytingov universitetov: analiz i kritika', Universitetskoye upravleniye: praktika i analiz, 2, pp. 70-80.

Komitet Gosudarstvennoy Dumy Po Mezhdunarodnym Delam (2022). Available at: https://interkomitet.ru/vneshnaya-politika/osnovopolagayuschiye-dokumenty/.

Korzun, V. A. (2012) The Climate Change: Causes, Forecasts, and Consequences for the World Economy. Moscow: IMEMO RAN.

Kościński, P. (2015) 'Russkij mir - rosyjska polityka sąsiedztwa', Sprawy Międzynarodowe, 68(3), pp. 71-87. 
Kuzyk, B. N. et al. (2004). Rossiya v prostranstve i vremeni. Moskva: Institut ekonomicheskikh strategiv.

Lukashin, Y. (2002) Proverka gipotez v ekonometrike. Moskva: IMEMO RAN.

Lukashin, Y. (2003) Adaptive Methods of Short-Term Forecasting of Temporal Rows. Moscow: Finansy i Statistika Publisher.

Lukashin, Y. (2010) Ekonometrika i prognozirovaniye. Moskva: Moskovskaya mezuhdunarodnaya vysshaya shkola biznesa MIRBIS (Institut).

Lukashin, Y. (2017) Prognozirovaniye sotsialno-ekonomicheskikh protsessov: uchebnoye posobiye. Berlin: Direkt-Media.

Pankova, L. V. (2016) Military Economics, Innovation and Security. Moscow: IMEMO.

Pantin, V. (2003) Cycles and Waves of the Global History: Globalization in Terms of History. Moscow: Novyi Vek Publishers.

Pantin, V. I. et al. (2016) Forecasting Social and Political and Conflicts in the West and in Russia. Moscow: IMEMO RAN.

RAND (2022). Available at: https://www.rand.org/.

Russell, B. (2004) Power: A New Social Analysis: Routledge Classics.

Saunders, P. J. (2019) Has Russia Established a New International Role? Russians Prospects as a 'Sovereignty Provider'. Available at: http://valdaiclub.com/a/highlights/has-russiaestablished-a-new-international-role/?sphrase_id=1392213.

Semenenko, I. S. et al. (2014) Political Change in a Global World: Theoretical and Methodological Problems of Analysis and Forecasting. Moscow: IMEMO.

Shpengler, O. (1918) Zakat zapadnogo mira. Available at: https://royallib.com/book/osvald_ shpengler/zakat_evropi.html.

Stratfor (2022). Available at: https://www.stratfor.com/.

The Carnegie Moscow Center (2022). Available at: https://carnegiemoscow.org/.

The Club of Rome (2022). Available at: https://clubofrome.org/.

The Correlate of War Project (2022). Available at: https://correlatesofwar.org/.

The Council on Foreign and Defence Policy (2022). Available at: https://css.ethz.ch/en/.

The Economic Intelligence Unit (2022). Available at: https://www.eiu.com/n/.

The International Institute for Strategic Studies (2022). Available at: https://www.iiss.org/.

The Stockholm International Peace Research Institute (2022). Available at: https://www.sipri.org/.

The Valdai International Discussion Club (2022). Available at: https://valdaiclub.com/.

Toynbee, A. (1949) A Study of History. Available at: http://nobsword.blogspot.com/1993_10_17_nobsword_archive.html.

Trejnis, Z. (1997) 'Armia elementem struktury aparatu państwowego', in Trejnis, Z. (ed.) Sity zbrojne $w$ państwie demokratycznym $i$ autorytarnym. Toruń: Wydawnictwo Adam Marszałek. 
Trenin, D. (2020) Confronting the Chalenges of Coronavirus. Available at: https://carnegie.ru/commentary/81335.

United Nations Environment (2019). Global Environment Outlook 6. Available at: https://www.unep.org/resources/global-environment-outlook-6.

World Future Society (2022). Available at: https://www.21stcentech.com/world-futuresociety-20-forecasts-2025/.

World Futures Studies Federation (2022). Available at: https://wfsf.org/.

Zolina, S. (2014) 'National energy strategies in the context of globalization. Energy as a platform for innovative development', in Zhukov, S. V. (ed.) Forecasting US Tight Oil Production. Moscow: IMEMO RAN. 